\title{
病棟リハビリテーションのための施設環境に関する研究 回復期リハビリテーション病棟を対象として
}

\section{A STUDY ON ENVIRONMENT FOR REHABILITATION TRAINING IN HOSPITAL WARDS}

In the case of convalescence rehabilitation

\author{
岩倉由貴子*, 岡 本和彦**, 長 澤 泰*** \\ Yukiko IWAKURA, Kazuhiko OKAMOTO and Yasushi NAGASAWA
}

\begin{abstract}
The aim of this study is to clarify planning principle of convalescent rehabilitation wards which are based on the aspect that the entire patients' stay in their ward is for the purpose of rehabilitation training. The observational researches were carried out in three hospitals. The followings are the results of the study.

1. The space for a certain kind of rehabilitation training is composed by the combination of "Elements", i.e. the groups of tools equipped with certain characters, which will lead to the difference of the training space in each hospital.

2. The space for patients who are spending out of bed was clarified.

3. The characters of the rehabilitation in each hospital were different, and the environmental necessities for rehabilitating should be considered not only from the training viewpoint, but also from the entire patients' stay in their ward, especially during their behavior out of the bed.
\end{abstract}

Keywords : convalescence rehabilitation ward, "Rehabilitation training in ward", training, spending out of bed, hospital 回復期リハビリテーション病棟,「病棟リハ」, 訓練, 離床, 病院

\section{1. はじめに}

\section{1-1 背景と目的}

1）回復期リハビリテーション病棟を取り巻く動向

回復期リハビリテーション病棟は、近年の医療供給体制の大幅な 変革により 2000 年に創設され、急性期を脱した一部の疾患患者の 受け皿として位置づけられている（図 1)。リハビリテーション（以 下、リ八）医療の流れにおいては、回復期リ八は、発症後約 1 ケ月 の急性期リ八を終えた後、家庭復帰を目的とした能動的で多彩な訓 練を中心とする段階となっている(図 2)。

在院日数短縮の流れを受けて、当該病棟はますます質の高いリ八 を提供することが求められている。

2）「病棟リ八」の概念

回復期リ八病棟は、 $\mathrm{ADL}$ 㳯 1 の向上、寝たきりの防止、家庭復帰を 目的とし、短期間で最大限の効果を引き出すようなリ八を行う病棟

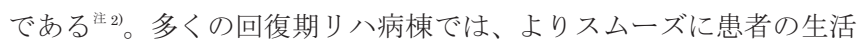
能力を確立させるために、従来の訓練室中心ではなく、病棟生活の 流れの中で行うリ八（＝「病棟リ八」）を理念としている。しかし、 具体的な実施状況やそのための施設環境は病院により様々で、現在 模索段階だと言える。

\footnotetext{
* (侏日建設計 修士(工学)

** 東京大学工学部建築学科 助教 $\cdot$ 博士 (工学)

*** 工学院大学工学部建築学科 教授·工博
}

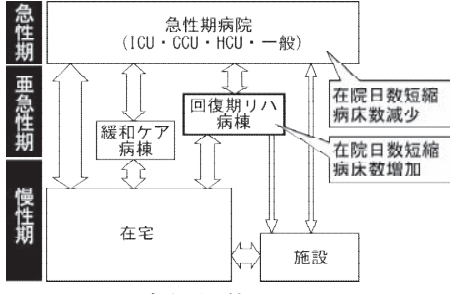

図 1 医療供給体制における 回復期リ八病棟の位置づけ

3）本研究の位置づけと研究の目的

当該病棟を扱う既往研究には、全国アンケート調查から病棟の運 営状況や患者属性、建築の状況等についての報告を行うもの 1) 3)や、 特定の病棟における観察調査に基づく患者生活や施設環境に関する 研究 (4) (6)がある。その中でも、病棟における ADLの実施状沉に関 するもの や、ベッドまわりの療養環境に焦点を当てたもの ${ }^{2}$ など、 病棟におけるリ八環境の一部に関する研究があるが、いずれも患者 生活全般におけるリ八を視野に入れたものではない。

そこで本論文では、患者生活全般をリハと捉え、そのための建築 環境を探っていく。施設構成の違う 3 病院におけるヒアリング調 查・観察調查をもとに、まず患者生活全体の概要を得た（3 章）後、
Nikken Sekkei Ltd., M. Eng.

Assistant Prof., Department of Architecture, Faculty of Engineering, the University of Tokyo, Dr. Eng.

Prof., Department of Architecture, Faculty of Engineering, Kogakuin University, Dr. Eng. 
訓練とそのための環境 ( 4 章)、さらに患者の離床とそのための環境 （5 章）について述べる。そして最終的に、当該病棟の理念である 「病棟リ八」を行うのに有効な施設環境についての知見を得ること を目的としている。

\section{1-2 調査方法}

\section{1-2-1 調査対象病院（表 3)}

本研究では、入院生活における訓練のあり方を探るために、訓練 室 ${ }^{\text {注 }}$ の位置の違いに着目した。そこで、病棟とは別のフロアに主な 訓練室が設けられている病院として A・B 病院を、病棟内に訓練室 が設けられている病院として C 病院を選定した。対象病棟は、A 病 院で 2 病棟 $(3 \mathrm{~F} \cdot 7 \mathrm{~F}) 、 \mathrm{~B}$ 病院・ C 病院では各 1 病棟とした。

\section{1-2-2 調査内容}

下記の 3 種類の調査を行った（表 1 ）。

1) ヒアリング調査

患者の入院生活・リ八の実施状況等概要を把握するために、病院 スタッフにヒアリングを行った。

2) 観察調查 $1:$ 特定の患者の継続的観察調查

各病院につき $2 \sim 4$ 名、計 10 名の特定の患者を選定し 注4)（表 6 ）、 1 日（ 7 時〜 21 時）の行為・場所を 3 ケ月にわたり（最多 3 回／ 人、のべ 25 回）連続的に観察し、平面図に行為を記録した。

3）観察調查 $2:$ 病棟共用部でのマッピング調查

4 病棟の病棟共用部注)老対象に、患者・スタッフ・その他の人と

表 1 調查日（2006 年）

\begin{tabular}{|c|c|c|c|c|}
\hline \multicolumn{2}{|c|}{} & A病院 & B病院 & C病院 \\
\hline \multicolumn{2}{|c|}{ ヒアリング調査 } & $9 / 6$ & $8 / 3 \cdot 9 / 7$ & $9 / 1$ \\
\hline \multirow{2}{*}{ 観察調査1 } & 1回目 & $9 / 28 \sim 29$ & $11 / 28 \sim 29$ & $10 / 17 \sim 18$ \\
\cline { 2 - 5 } & 2回目 & $10 / 26 \sim 27$ & $12 / 21 \sim 22$ & $11 / 15 \sim 16$ \\
\cline { 2 - 5 } 3回目 & $11 / 23$ & $1 / 16(2007$ 年) & $12 / 13 \sim 14$ \\
\hline \multirow{2}{*}{ 観察調査2 } & 1回目 & $9 / 30 \cdot 10 / 28$ & $11 / 28$ & $10 / 19$ \\
\cline { 2 - 5 } & 2回目 & $11 / 23 \cdot 24$ & $11 / 29$ & $11 / 17$ \\
\hline
\end{tabular}

場所を 10 分おき（7 時〜21 時）に病棟平面図に記録した（A病院 3 階全 150 データ、 7 階全 158 データ、B 病院全 165 データ、C 病院 2 階 161 データ、3 階全 163 データ)。

\section{2. 調査対象病院の特徵}

\section{2-1 患者属性・スタッフ構成}

ヒアリング調查より、患者属性・スタッフ構成を表 2 にまとめる。

1) A 病院: 3 階は整形外科系が多く（約 7 割）、7 階は脳血管系が多 い(約 7 割) 病棟となっている。3 階のほうが日常生活自立度の 高い患者が多く、スタッフ数が少ない。

2) B 病院：ほぼ全員が脳血管系患者である。他病院に比心゙男性の割 合が多く、自立度の低い患者が多い。ほとんどのスタッフ数が他 病院に比べて多い。

3) $\mathrm{C}$ 病院 : 約 6 割が脳血管系であるが、2 階は自立度の低い患者、 3 階は高い患者が多い。

表 2 調查対象病院・病棟の患者属性とスタッフ構成

\begin{tabular}{|c|c|c|c|c|c|c|c|c|c|c|}
\hline & & \begin{tabular}{|c} 
A 病院) \\
$(3 F)$
\end{tabular} & \begin{tabular}{|c} 
A 病院 \\
$(7 F)$
\end{tabular} & 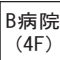 & C)病院 & & \begin{tabular}{|c|c|} 
A病院 \\
$(3 F)$ \\
\end{tabular} & $\begin{array}{c}\text { A病院 } \\
(7 F)\end{array}$ & $\begin{array}{c}\begin{array}{c}\text { B病院 } \\
(4 \mathrm{~F})\end{array} \\
\end{array}$ & C 病院 \\
\hline & 脸口 & \begin{tabular}{|l|l|}
25.6 \\
7
\end{tabular} & 69.6 & 97.9 & 59.4 & 病床数(床) & 40 & 40 & 48 & \\
\hline 疾 & 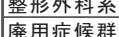 & \begin{tabular}{|l}
10.9 \\
0.0
\end{tabular} & $\frac{21.9}{1.7}$ & \begin{tabular}{|l|}
0.0 \\
\end{tabular} & 27.7 & & 0.3) & & & \\
\hline & 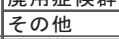 & 3.5 & 0.8 & 2.1 & $\begin{array}{l}9.1 \\
3.2 \\
\end{array}$ & & (10.3) & $1(0.3)$ & $0.6)$ & \\
\hline 6 & J & $\overline{0.0}$ & $\begin{array}{l}3.4 \\
\end{array}$ & $\begin{array}{l}4.2 \\
\end{array}$ & 5.9 & 看護師 & $14(3.5)$ & $14(3.5)$ & $22(4.6)$ & 19 \\
\hline 自常常 & $\frac{A}{B}$ & 62.5 & \begin{tabular}{|l|}
27.8 \\
62.9
\end{tabular} & $\begin{array}{r}6.3 \\
77.9\end{array}$ & \begin{tabular}{|l|}
19.3 \\
59.2
\end{tabular} & |看護補助 & $8(2.0)$ & $10(2.5)$ & $12(2.5)$ & \\
\hline 度活 & & 0.0 & \begin{tabular}{|l|}
5.9 \\
\end{tabular} & 37.5 & 11.7 & |PT & 7 & $9(2.3)$ & $6(3.3$ & \\
\hline & 不明 & 0 & 0.0 & 4. 2 & 3.9 & & & & & \\
\hline & 正常 & 72.0 & 85.6 & 22.9 & 46.1 & от & $4(1.0)$ & $8(2.0)$ & 0,2 & \\
\hline & T & 20.4 & 10.2 & 22.9 & 18.1 & & & $3(8.8)$ & (1.3) & \\
\hline & \begin{tabular}{|l|} 
II \\
III \\
If \\
\end{tabular} & 0 & $\begin{array}{l}3.4 \\
0.8\end{array}$ & $\frac{14}{33}$ & 9.6 & $\mid \mathrm{Si}$ & & & & \\
\hline & IV & 0 & 0.0 & \begin{tabular}{|l|l|}
2.1 \\
\end{tabular} & 6.4 & MSV & $2(0.5)$ & $2(0.5)$ & $2(0.4)$ & $2(1$ \\
\hline 羊 & M & 5 & 0.0 & 0 . & 0.0 & & o] & $1(0.3)$ & $2(0$. & \\
\hline & 不明 & 0 & 0.0 & 4. 2 & 3. 9 & & & & & \\
\hline 性別 & 男 & 316 & 43.2 & 66.7 & 39.9 & 薬刘 & 0 & $1(0.3)$ & & $1(0$. \\
\hline 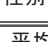 & 女 & 68.4 & 56.8 & 33.3 & $\begin{array}{l}60.1 \\
72.2\end{array}$ & & 0 & & $2(0.4)$ & $3(0$. \\
\hline 平均 & 年齢 & 72.7 & 69.5 & 65. & 72.3 & & & & & \\
\hline
\end{tabular}

表 3 対象病院概要（2006 年現在 $)$

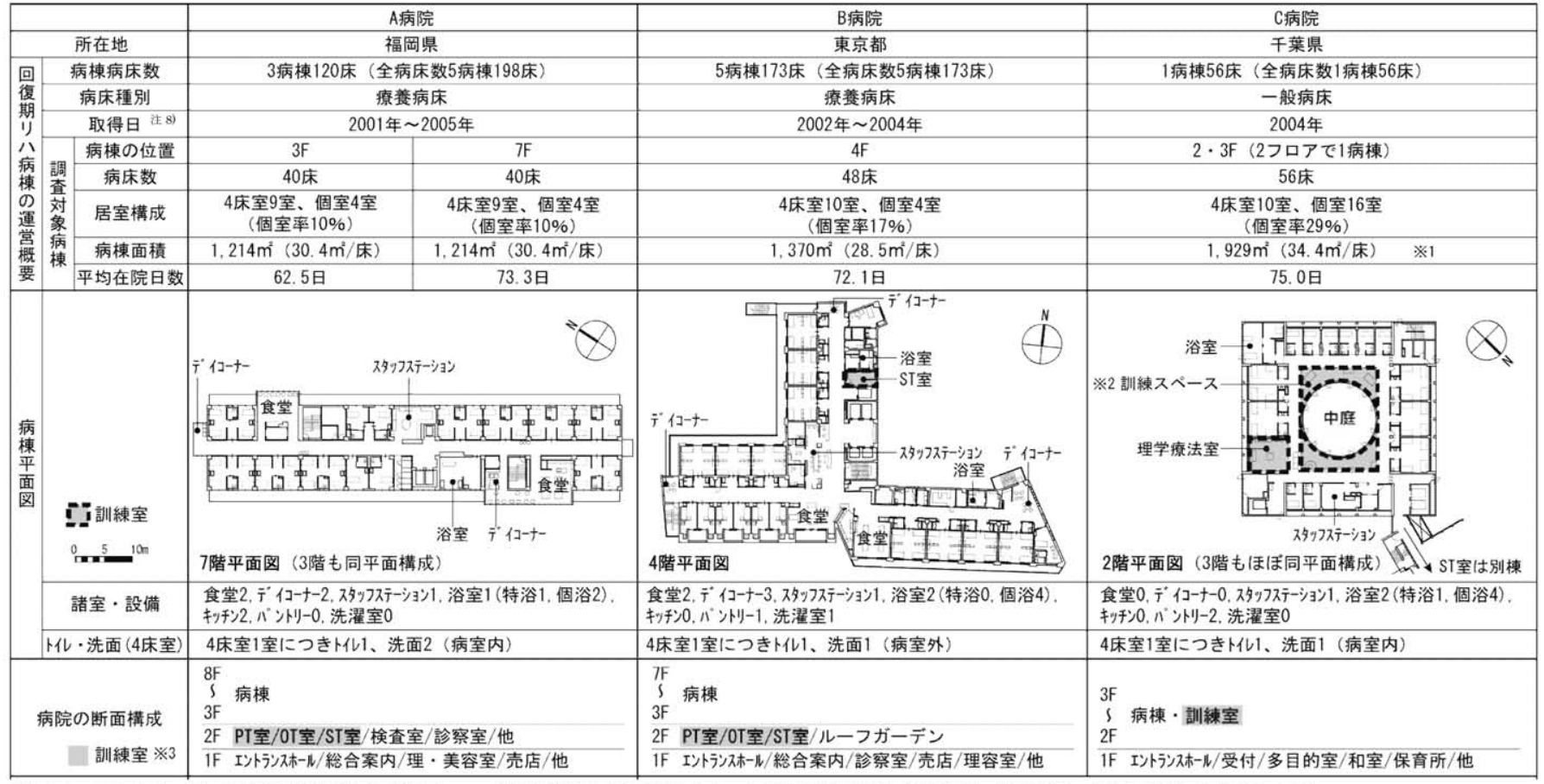

※1 2フロアの合計。また訓練室面積約 $280 \mathrm{~m}^{2}$ を含める。 ※2 病院は図示の訓練スペースと理学療法室が、回復期リ八病楝取得に必要な申請上の訓練室である。

※3 A B B 病院の訓練室は外来患者も利用するが、C病院における訓練室は、入院患者のみ利用する（外来患者は、併設の総合病院内リ八室を利用する）。 


\section{2-2 各病院の建築的特徵}

1) 病棟の特徵

$\mathrm{A}$ 病院の病棟は中廊下型で、食堂、デイコーナーが南北 2 ケ所 ずつ、また食堂にはキッチンが設けられている。4 床室内にはトイ レが 1 つ、洗面が 2 つ設けられている。

$\mathrm{B}$ 病院病棟も中廊下型で、スタッフステーションの近くに食堂 2 つ、デイコーナー 3 ケ所、浴室 2 室、洗濯室、また 2 食堂に隣接し てパントリーが設けられている。また言語療法 $(\mathrm{ST})$ 室が 1 室設け られている。各 4 床室前にトイレ・洗面が設置されている。

$\mathrm{C}$ 病院は、総合病院に併設する形で開設された、回復期リ八病棟 1 病棟のみの病院で、訓練スペースが病棟内に設けられているのが 特徴である。中廊下型の $\mathrm{A} \cdot \mathrm{B}$ 病棟とは違い、円形の中庭に面した 部分に訓練スペース・廊下を設け、それを囲むように病室・スタッ フステーション等を配置した平面構成である。また、食堂はなく、 訓練スペース・廊下部分の一部にテーブルが並ベられており、食堂 として使用されている。その他、浴室、パントリー、理学療法室が 設置されている。トイレ・洗面は、各病室内入口に設けられている。 2) 訓練室の設置形態の違い

3 病院において訓練室の設置形態に違いがある。 $\mathrm{A} ・ \mathrm{~B}$ 病院におけ る主な訓練室 $(\mathrm{PT} \cdot \mathrm{OT} ・ \mathrm{ST}$ 室）が別フロアに設けられているのに 対し、 $\mathrm{C}$ 病院は訓練室が病棟内に設けられている。前者を<病棟一 訓練室分離型 $>$ 、後者を $<$ 病棟一訓練室一体型 $>$ とする (表 4 )。

2-3 各病院の訓練に対する理念（ヒアリング調査より）

$\mathrm{B} \cdot \mathrm{C}$ 病院は、「病棟での生活に沿った訓練を行う」ことを理念と しているが、A病院では、病棟は生活の場とするために、「訓練は訓 練室で」行うことを理念としている（表 4)。

表 4 訓練室の設置形態と、訓練に対する理念

\begin{tabular}{|c|c|c|c|}
\hline & A病院 & B病院 & C病院 \\
\hline 訓練室の設置形態 & く病棟-訓練室分離型〉 & く病棟-訓練室一体型〉 \\
\hline 訓練に対する理念 & $\begin{array}{c}\text { 「訓練は訓練室で } \\
\text { (病棟は生活の場)」 }\end{array}$ & 「病棟での生活に沿った訓練を行う」 \\
\hline
\end{tabular}

\section{3. 患者生活}

\section{3-1 スケジュールと生活行為の分類}

ヒアリング調查から、各病院が定めている患者の 1 日のおおまか なスケジュールをまとめ(図 3)、患者の行為の分類を行った(表 5)。

各病院とも共通して、患者の自立した生活を目指し、ADL（食事・ 整容・更衣・排泄・入浴等) ・訓練（個別療法等）を患者スケジュー ルとして定めている。また医療行為もスタッフにより定められた行 為である。これらの行為以外の余暇時間の中で、患者がじのように 離床時間を過ごすかを抽出するために、行為の分類において、スケ ジュールとして決められた行為以外を離床と臥床に分類した。

\section{3-2 患者生活の概要}

各患者の各調查日における自立度・滞在場所と滞在時間・行為に ついて図 4 にまとめ、患者生活に関する知見を以下にまとめる。

1）医療行為

生活における医療行為の時間としては、看護師等によるバイタル チェック・口腔ケア等わずかであり、主に病室で行われている。

2) $\mathrm{ADL}$

3 病院とも、患者の $\mathrm{ADL}$ の向上を目指し、患者自身で、あるいは

\begin{tabular}{|c|c|c|c|c|c|c|}
\hline \multicolumn{4}{|c|}{ 内は場所 } & \multicolumn{2}{|c|}{ 表 5} & 生活行為の分類 \\
\hline \multirow{2}{*}{\multicolumn{2}{|c|}{ 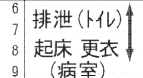 }} & \multirow[b]{2}{*}{ 个朝食（食堂） } & \multirow{4}{*}{ 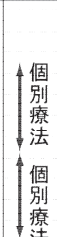 } & \multicolumn{2}{|c|}{ 行為 } & 内容 \\
\hline & & & & \multicolumn{2}{|c|}{ 医療行為 } & $\begin{array}{l}\text { バイタルチェック・ } \\
\text { ロ腔ケア・オムツツ交換等 }\end{array}$ \\
\hline & \multirow{2}{*}{ 昼食 (食堂) } & \multirow{4}{*}{ 入浴 } & & \multicolumn{2}{|c|}{ ADL } & $\begin{array}{l}\text { 日常生活動作（食事·整容 } \\
\text { ·更衣·排泄 · 入浴等） }\end{array}$ \\
\hline & & & & \multicolumn{2}{|c|}{ 訓練 ${ }^{i 29}$} & $\begin{array}{l}\text { 療法士による単位として } \\
\text { の訓練 }\end{array}$ \\
\hline & $\begin{array}{c}\text { 夕食(食堂) } \\
\text { 菻磨き (洗面所) }\end{array}$ & & & & 離床 & $\begin{array}{l}\text { 上記以外の離床時間の } \\
\text { 行為を指す }\end{array}$ \\
\hline & $\left|\begin{array}{c}\text { 更衣 入眼 } \\
\text { 病 }\end{array}\right|$ & & & & 臥床 & $\begin{array}{l}\text { バッドに横たわって } \\
\text { いること }\end{array}$ \\
\hline
\end{tabular}

図 3 患者の 1 日のスケジュール

表 6 観察調查 1 対象患者の属性

\begin{tabular}{|c|c|c|c|c|c|c|}
\hline 病院 & 患者 & 性別 & 年齢 & 主疾病 & 障害 & $\begin{array}{l}\text { 認知症高齢者の } \\
\text { 日常生活自立度 }\end{array}$ \\
\hline \multirow{4}{*}{ A } & (1) & 女 & 84 & 骨盤骨折·脳梗塞 & 左片麻盘 & $\frac{1}{\Pi a}$ \\
\hline & & 女 & 81 & $\begin{array}{c}\text { 脳梗塞 } \\
\end{array}$ & 左片麻舫 & \\
\hline & & 女 & 80 & 左大腿骨軽尝子間骨折 & & \\
\hline & (4) & 安 & 103 & 左大腿骨骨間部骨折 & & \\
\hline \multirow{2}{*}{ B } & (1) & 男 & 61 & 脸出血 & 左片麻艆 & \\
\hline & (2) & 勇 & 51 & 脳出血 & 左片楸瘇 & $\overline{I I b}$ \\
\hline \multirow{3}{*}{ c } & (1) & 女 & 68 & 脸岃耑 & 右㭊栄瘙 & \\
\hline & (2) & 䙲 & 31 & 脑出血 & 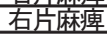 & IV \\
\hline & & 女 & \begin{tabular}{|l|}
87 \\
85 \\
\end{tabular} & $\begin{array}{l}\text { 左大腿骨転子間骨折 } \\
\text { 左大腿骨頸部骨折 }\end{array}$ & & \\
\hline
\end{tabular}

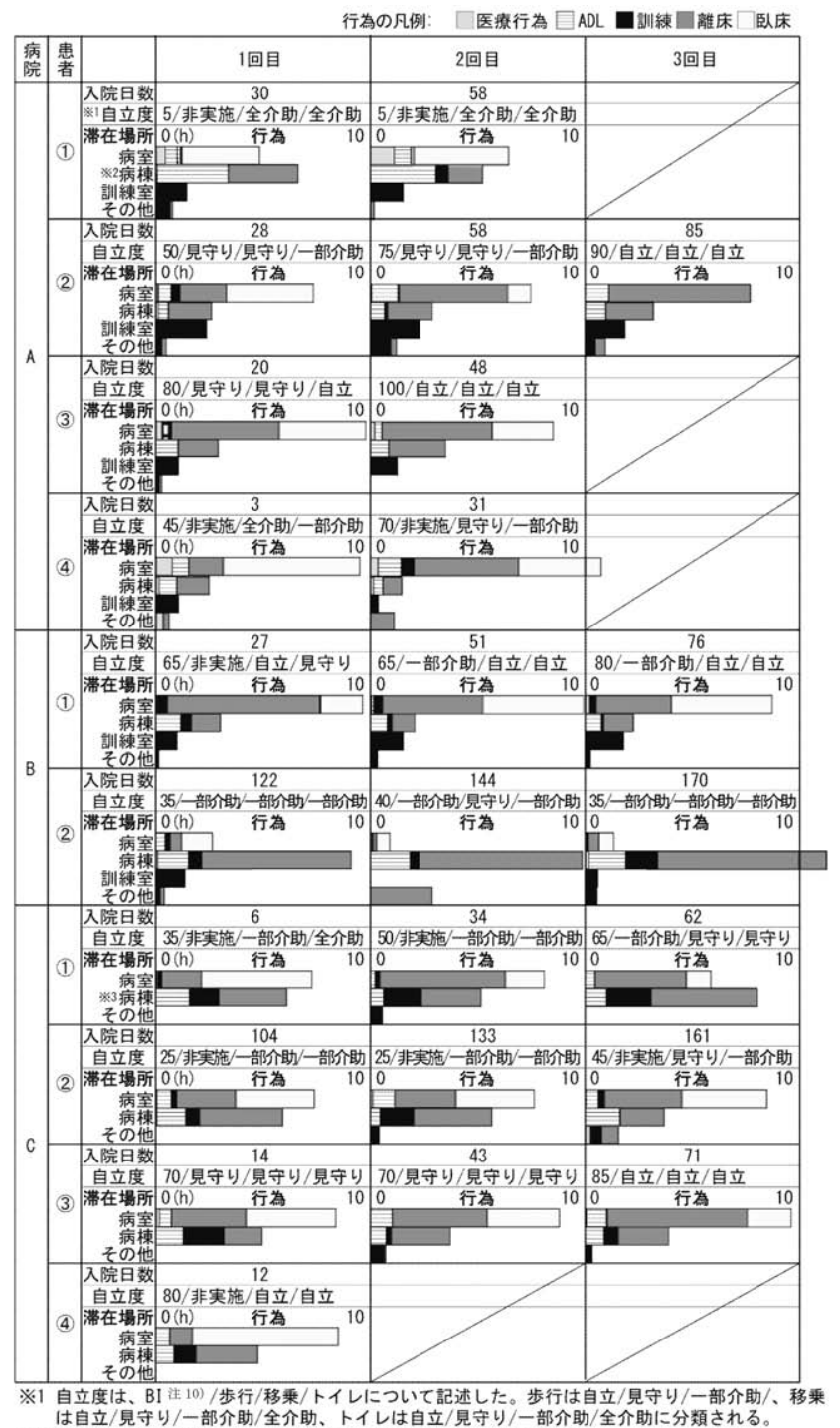

は自立/見守り/一部介助/全介助、トイレは自立/見守り/一部介助/全介助に分類される。

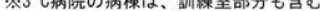

図 4 観察調查 1 対象患者の滞在場所・時間と行為 
スタッフが伴い、可能な限り $\mathrm{ADL}$ を行う。食事は病棟内の食堂で、 整容（歯磨き・洗顔・整髪・化粧等）は病室・洗面で、更衣は病室 で、排泄はトイレ（あるいはおむつ、ポータブルトイレ）で、入浴 は病棟内の浴室で行う（B病院では、家庭環境により近い形で行う ため、入浴は個浴のみである)。入浴頻度は、 $\mathrm{B} \cdot \mathrm{C}$ 病院では、 1 回 /1 2 日程度、 $\mathrm{A}$ 病院では、介助浴・機械浴は 2 回/週、自立浴は患 者希望により毎日も可、となっている。

3) 訓練

3 病院とも、各患者は毎日スケジュールを組まれ、9 時前後から昼 食時を除き 16 時半前後までの間に 1 ～回/日いずれかの個別療法を 行う（今回の調查では集団療法は観察されなかった）。訓練は $\mathrm{A} ・ \mathrm{~B}$ 病院においては病室・病棟・訓練室・その他において、C 病院にお いては病室・病棟（訓練室含む）・その他において観察された。訓練 については、4 章で詳しく言及する。

4）その他

3 病院ともにおいて、患者の活動性を上げるために、医療行為・ $\mathrm{ADL}$ ・訓練の時間以外の余暇時間には安静だけでなく、できるだけ 離床するよう呼びかけている。離床に着目すると、3 病院とも病室・ 病棟が主な離床場所となっている。 $\mathrm{A} ・ \mathrm{~B}$ 病院において、認知症高 齢者の日常生活自立度の低い患者の離床場所は、主に病室以外の病 棟となっている $(\mathrm{A}$ 病院患者(1)・B 病院患者(2)）。また、大きく自立 度が伸びた患者は、離床時間が増加している傾向が見られる（A 病 院患者(2)・(4)、C 病院(1)・(3)。離床については、5 章で詳しく言及 する。

\section{4. 訓練のための空間}

この章では、訓練（＝表 5 の「訓練」）の大部分を占める $\mathrm{PT} ・ \mathrm{OT}$ 訓練について記述する ${ }^{\text {is } 11}$ 。

\section{4-1 訓練場所}

訓練（PT・OT 訓練）における滞在場所と滞在時間を、観察調査 1 結果より、各病院ごとにまとめる（図 5)。また、観察調査 2 より、 病棟共用部における訓練が見られた患者数を示寸（図 6)。

$\mathrm{A}$ 病院における観察調査 1 対象患者の訓練場所は、9 割近くが訓 練室・階段とその周辺（訓練室間の廊下、ルーフテラス等）である （図 5)。また、他病院に比心゙病棟共用部で訓練を行っている患者は 少なく（図 6)、主に訓練室で訓練を行っていると言える。

B 病院では、訓練室が $55 \%$ 、病棟が $32 \%$ 利用されている。階段が $8 \%$ 之、他病院より多い。また、病棟の食堂の利用が他病院より多 く、その他の病棟共用部（廊下等）も利用される（図 5)。訓練室と 病棟の両方で訓練を行っているといえる。

訓練室が病棟に位置する $\mathrm{C}$ 病院では、観察調查 1 対象患者の訓 練場所は、病棟における訓練が約 9 割を占める（図 5)。また、病 棟共用部での訓練が他病院より多く（図 6)、病棟内でも主に訓練 スペースで訓練を行っていると考えられる。また自立度の低い患 者の多い 2 階病棟より、自立度の高い患者の多い 3 階病棟のほう が訓練患者数は多くなっている。

\section{4-2 訓練の分類と各訓練の空間構成}

次に、観察調查 1 と観察調査 2 の一部より、各病院における具体的 な訓練内容と利用場所、道具等に着目して図 7 にまとめる。本研究 では、その空間の性質により、訓練を I 〜 IIIの 3 つに分類した。
図 $5 A \sim C$ 病院における訓練場所 (観察調查 1 対象患者の平均滞在時間)
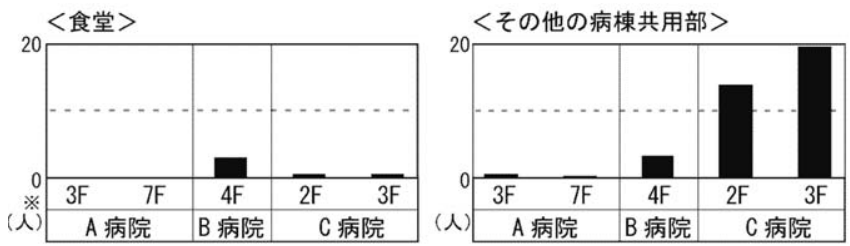

図 6 病棟共用部において訓練が観察された患者の数 (観察調查 2 より)

※各病院について 100 床あたりに換算した 1 時間あたりの平均患者数 (1 時間のうちに 10 分おき、計 6 回調査したため最大 600 とする)

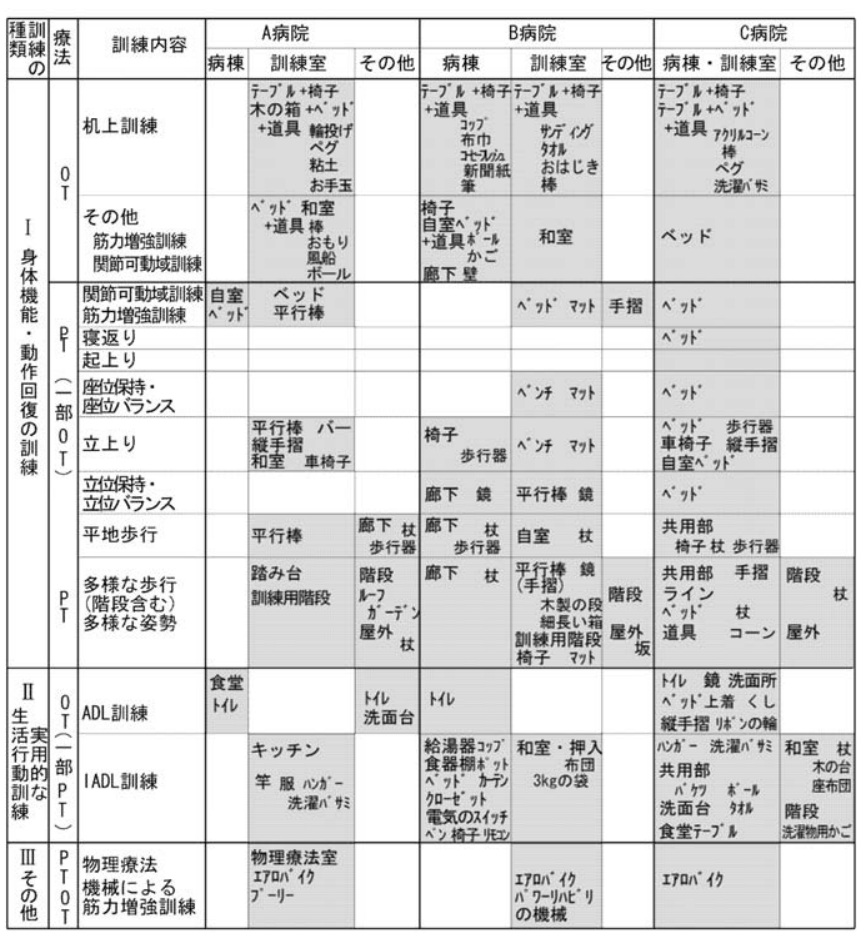

(網がけは訓練が観察された場所を示す)

図 $7 \mathrm{~A} \sim \mathrm{C}$ 病院における訓練場所と訓練内容・道具 
1）訓練 I：身体機能・動作回復の訓練

各身体機能・動作 $(\mathrm{PT}$ 訓練 : 寝返り・起上り〜歩行・多様な姿 勢、OT 訓練：上肢訓練）の回復のための訓練では、図 8 に示すよ うな様々な道具が用いられる。これらの道具は、広さや高さ・可動 性などのある性質を持つ道具のグループ ( $\mathrm{a} \sim \mathrm{f})$ にまとめることが でき、これを「要素」と定義する。訓練 I のそれぞれの訓練空間は、 表 7 に示すように、「要素」を組み合わせることで構成されており、 「要素」さえ揃えば可能な、場所を選ばない訓練だといえる。

次に具体例をいくつか示す。

・ストレッチ訓練

$\mathrm{C}$ 病院病棟内の訓練スペースにはベッド（要素 a）が置かれ、こ れを利用してストレッチ訓練を行っている（図 12）。

\section{・机上訓練}

腰掛けるもの（要素 $\mathrm{b})$ 、机上面（要素 $\mathrm{c}$ )、可動の道具（要素 $\mathrm{e}$ ) を用いて行われる。 $\mathrm{B}$ 病院の食堂では、椅子、テーブル、コップと 布巾を用いてこの訓練を行っていた（図 9）。

・立上り〜歩行への空間

立上りには、座る高さのもの（要素 b）と立上り時に体を支える もの（要素 d）が必要であり、歩行するには空間の広がり（要素 f） が必要である。B 病院での一例として、それぞれ車椅子、手摺、廊 下を用いて、病棟内にてこの訓練を行っていた（図 10）。

・多様な歩行の空間

歩行が安定してきた患者は、歩行距離を伸ばすだけでなく、バリ エーションのある歩行訓練を行う。C 病院では、広がりのある空間

（要素 f）で可動の道具（要素e）を用いた訓練が見られた（図 12） その他、階段 $(\mathrm{A} \sim \mathrm{C}$ 病院 $) \cdot$ ルーフテラス $(\mathrm{A}$ 病院 $)$ ・屋外の道も 有効な場である。

2）訓練 II ：実用的な生活行動訓練 （ADL・IADL 訓練涪5)

ADL 訓練としては、食事訓練・トイレ訓練・整容訓練が観察され たが、 3 病院ともにおける訓練場所は、それぞれ食堂（病棟）、トイ レ(主に病棟、 $\mathrm{A}$ 病院においては $2 \mathrm{~F}$ のトイレの利用が見られたが、 設備は病棟トイレと同じである)、洗面所（病棟）で行っている。 IADL 訓練としては、料理訓練（病棟あるいは訓練室のキッチン）、 洗濯物干しの訓練（訓練室の物干し・洗濯ばさみ等を用いる）、掃除 訓練（病室のベッド周り）、さらには退院後の家庭環境を擬似的に再 現しての生活動作の訓練も観察された（図 11)。また、ヒアリング 調查からは各病院において屋外施設での買い物訓練も実施している。 ADL 訓練は、病棟生活での ADL 確立につながるよう病棟で行われ ることが多く、IADL 訓練は、病棟・訓練室において、退院後の生 活を想定した模擬的な空間で行われることが多いようである。

3) 訓練 III

物理療法室での物理訓練、筋トレのための各種機械による訓練等、 特定の設備を必要とする訓練である。

\section{4-3 各病院における訓練空間の特徵}

訓練 I は、先述のように図 8 にあげた要素を取り入れることによ り、様々な場所で（訓練室でも病棟でも）訓練が可能となる訓練で ある。その行われ方は病院により大きく異なり、各病院の訓練方法 を特徴づけるものとなっている。

1) $\mathrm{A}$ 病院 : 病院の方針（2-3 参照）により、訓練 I は主に訓練室を 中心に行い、病棟ではほとんど行わない。病棟生活につながる訓練

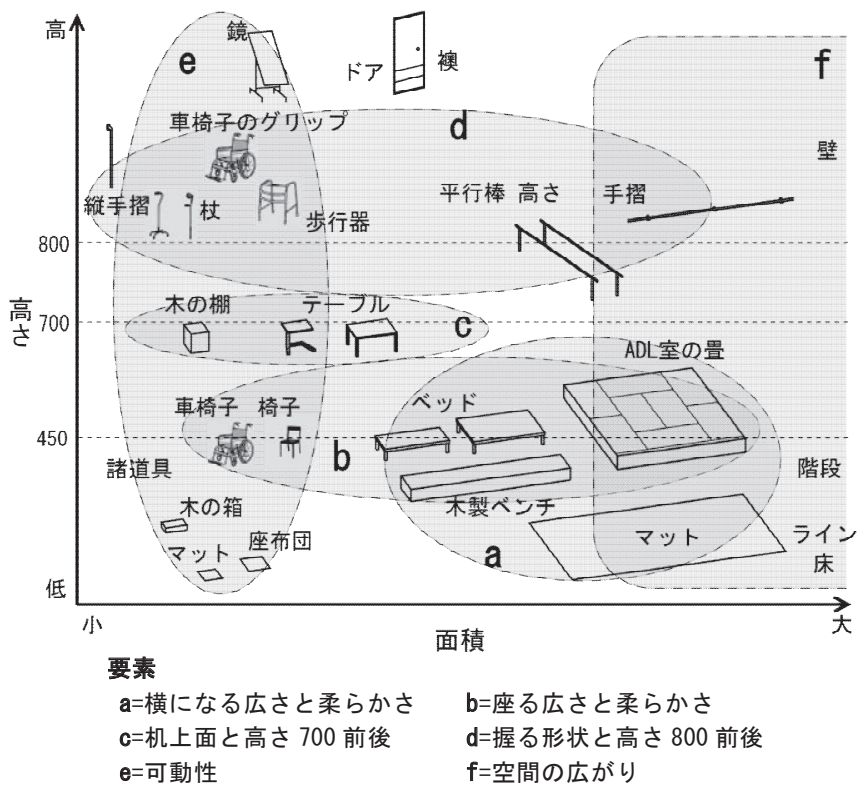

図 8 訓練 I の空間を構成する道具

表 7 訓練 I 空間の要素による構成

\begin{tabular}{|c|c|c|c|}
\hline & 姿勢 - 動作 & 構成要素 & 訓練内容 \\
\hline 1 & 臥位 & a & 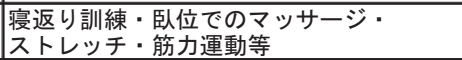 \\
\hline & $\begin{array}{l}\text { 座位 } \\
\text { (椅座位) }\end{array}$ & b & $\begin{array}{l}\text { 座位でのマッサージ・ストレッチ・筋力運動等 } \\
\end{array}$ \\
\hline & 起上り & $a+b$ & 起上り訓練 \\
\hline & 机上動作 & $b+c+e$ & 0T訓練の机上動作訓練 \\
\hline & 移乗動作 & $\mathrm{b}$ & 車椅子移乗訓練 \\
\hline & 立上り & $b+d$ & 立上り訓練 \\
\hline & 歩行 & $(b+d+)$ & \begin{tabular}{|l|l|} 
歩行訓練 \\
\end{tabular} \\
\hline & \begin{tabular}{|l} 
立位バランス \\
多様な歩き方
\end{tabular} & $(e+d+) f$ & $\begin{array}{l}\text { 咅位バランス訓練(よく鏡や手喟を使う) } \\
\text { 多様な歩行（横歩き・障害物をけけて歩く } \\
\text { ブロックによる段差を登る等 }\end{array}$ \\
\hline 9 & 多様な姿勢 & $a \cdot b \cdot e$ 等 & $\begin{array}{l}\text { その他多様な姿勢・動き } \\
\text { (床からの立上り等) }\end{array}$ \\
\hline
\end{tabular}

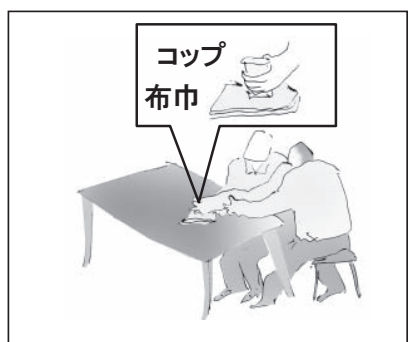

図 9 机上訓練の例 (B 病院病棟食堂)

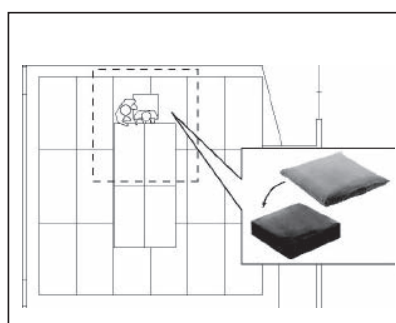

座布団を木の箱の上に乗 せ自宅の椅子の高さにす る。たたみ・座卓高さも自 宅と同じ条件である。

図 11 生活行動訓練の例 (C 病院 1 階和室 $)$

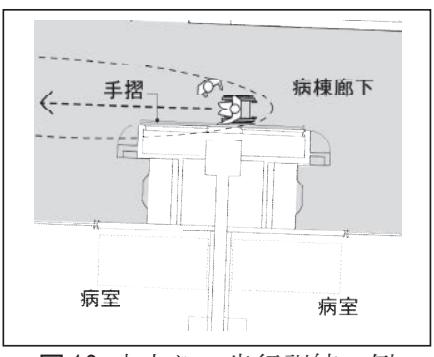

図 10 立上り〜歩行訓練の例 (B 病院病棟廊下)

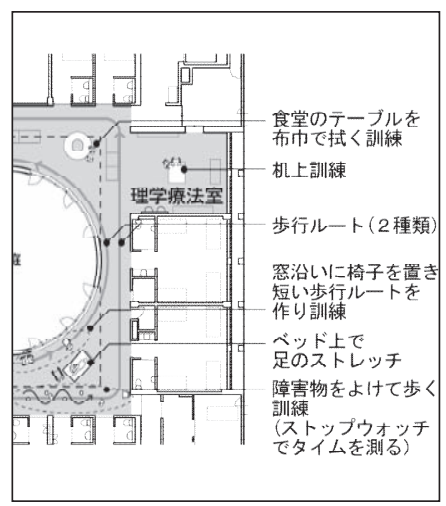

図 $12 \mathrm{C}$ 病院病棟共用部における 様々な訓練の様子 
II の $\mathrm{ADL}$ 訓練は、主に病棟で行う。

2) B 病院 : A 病院と同じ<病棟一訓練室分離型>であるが、訓練室 以外に、病棟内廊下・病室・食堂を舞台に、手摺や車椅子・ベッド・ テーブル・食器等の日常生活の道具を利用し、病棟内であらゆる訓 練を行っている。

3) $\mathrm{C}$ 病院 : 病棟の訓練スペースでは、訓練用のベッドを設置し、さ らに可動の道具（マット・歩行器・杖・テーブル等）を活用するこ とで、病棟内での様々な訓練を可能にしている。また円形の中庭を 取り囲む病棟共用部（訓練スペース・廊下）の形は、患者の歩行練 習にも有効なスペースとなっている（図 12）。

\section{4-4 考察 : 訓練に必要な空間}

1）様々な症状、自立度に対応できる、多様な訓練空間

当該病棟入院患者は、症状、自立度が様々であり、その段階に応 じて訓練空間も異なる。 $\mathrm{B} ・ \mathrm{C}$ 病院病棟での訓練 I においては、可 動の道具を用いて各患者に適した様々な訓練空間を作っているとい える。また、自立度の向上に伴い歩行距離を拡大させる環境（廊下 の長さ・屋内一屋外一の連続性等）も重要であろう。患者によって は訓練吕のための設えも必要である。

2）退院後の生活環境に類似した環境

入院の目的は家庭復帰であり、各患者の退院後の生活を視野に入 れた訓練環境を用意することが重要である。3 病院ともにおいて病 棟での ADL 訓練を行っているが、そのための食堂・トイレ・洗面・ 病室も、退院後の家庭環境を視野に入れた設計が必要である。また、 キッチンをはじめ、さらに多様な模擬的な環境（運転訓練設備、シ ヨッピング空間等）の院内への併置や、訓練において屋外施設の利 用をも見込んだ病院の配置計画も有効であると考えられる。

\section{5. 離床のための空間}

本章では、スタッフにより課されている訓練以外に、離床行為も 患者のリ八に有効であると捉え、患者の離床のし方に焦点を当てる。

\section{5-1 各病院における患者の離床場所と行為}

先述のとおり ( 3 章)、3 病院ともにおいて病棟・病室が患者の主 な離床場所である。

\section{5-1-1 病棟共用部}

図 13 は、観察調查 2 をもとに、病棟共用部（食堂注 13 ) ・その他） の行為と患者数をまとめたものである。離床行為（自主訓練・飲食・ 会話・趣味・移動・その他）には、表 5 の行為分類の「離床」と、 $\lceil\mathrm{ADL}$ 中の「食事（3 病院ともにおいて食堂で行われる）」を含め た。また図 $14 \sim 16$ に、 $\mathrm{A} \sim \mathrm{C}$ 病院病棟共用部における患者の離床行 為を示した。

\section{1) $\mathrm{A}$ 病院}

食堂は、食事以外に、余暇時間におけるお茶・趣味・アクティビ ティ 染14に使われており、また重症患者がスタッフに見守られて離床 する場所となっている。また、廊下やデイルームでの自主訓練・会 話等も観察された。A 病院の特徵としては、食堂に食堂専任スタッ フがつき、キッチンを利用した料理会等（誰でも参加可能）を日常 的に行うなど、訓練ではなく生活の中で IADL 能力を高める工夫を 行っており、生活的なり八を行っているといえる。また、他病院に くらべ、食堂における会話が多いのが特徴である（図 13）。 2) B 病院
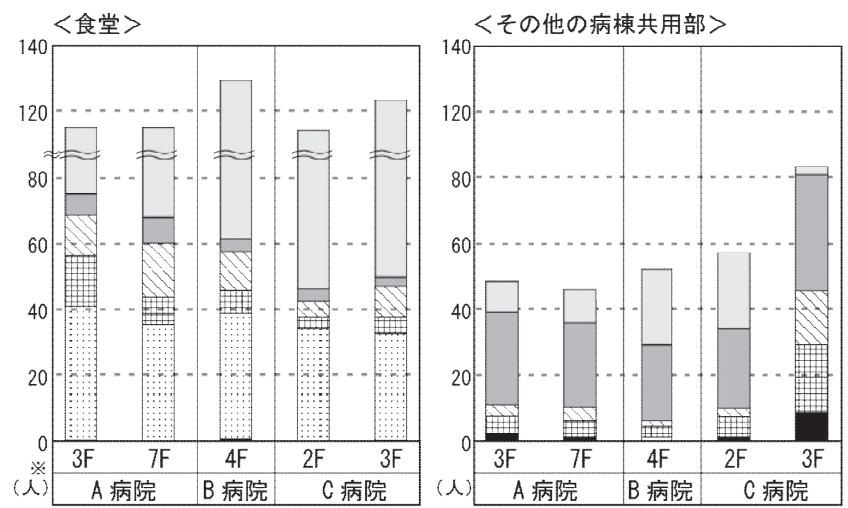

口自主訓練回飲食四会話 趣味 $\square$ 移動 $\square$ その他

（飲食：食事・お茶等 / 趣味: TV・読む・書く·電話等 / その他 : 無為・眠る・外を見る等を含む)

図 $13 \mathrm{~A} \sim \mathrm{C}$ 病院の病棟共用部における行為と患者数

(観察調査 2 より)

※各病院について 100 床あたりに換算した 1 時間あたりの平均患者人数 (1 時間のうちに 10 分おき、計 6 回調査したため最大 600 とする)
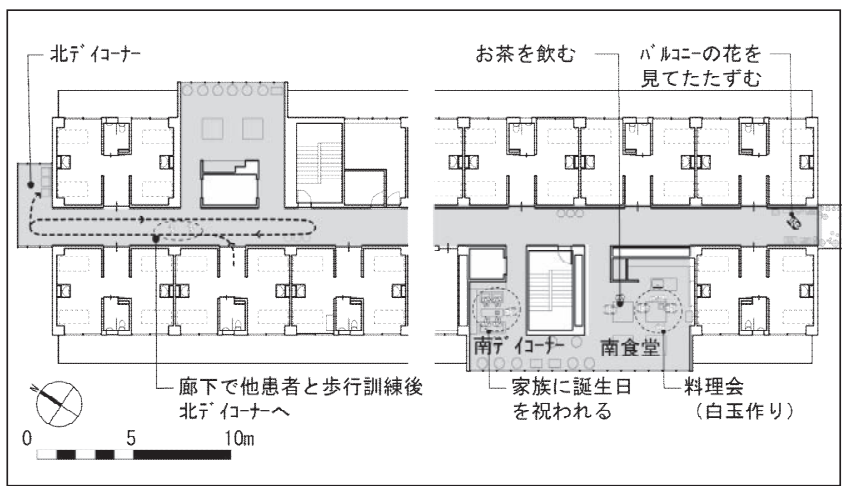

図 $14 \mathrm{~A}$ 病院病棟共用部における患者の離床行為例

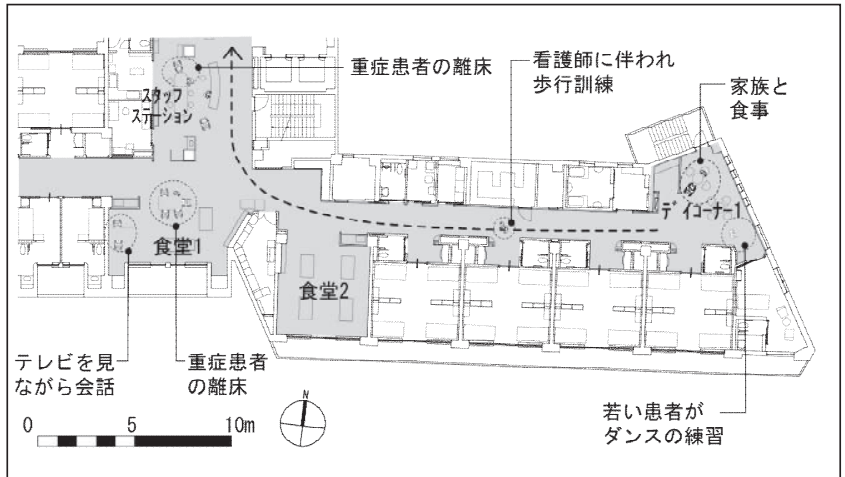

図 15 B 病院病棟共用部における患者の離床行為例

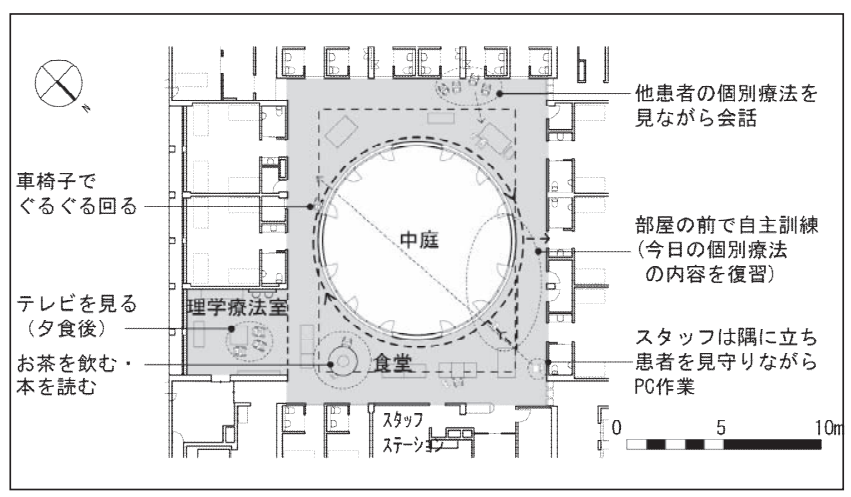

図 $16 \mathrm{C}$ 病院病棟共用部における患者の離床行為例 
食堂は $\mathrm{A}$ 病院と同様、食事・お茶・趣味の場所となっている。重 症患者の離床場所としては、食堂以外にスタッフステーションも使 われる。 $\mathrm{B}$ 病院でも食堂に必ず 1 人はスタッフがついて患者の離床 を促しており、3 病院の中では食堂における離床患者数が最も多い。 また廊下では、個別療法とは別に、スタッフによって歩行訓練が行 われている (図 13 では「その他」に分類)。他病院に比心゙、患者同 士の会話が少ないのは、B 病院患者の自立度が全体的に低いことが 影響していると考えられる。

3) $\mathrm{C}$ 病院

食堂は他病院と同様、食事の場として利用される。病棟共用部は 自主訓練の場・会話の場と、多様な離床空間として利用され、特に 他病院に比べ自主訓練・会話が多いのが特徵である（図 13、特に自 立度の高い 3 階において多い)。重症患者の離床場所としては、病 棟共用部全体が利用される。

\section{5-1-2 病室}

観察調查 1 をもとに、患者の主な離床場所の一つである病室の使 われ方の例を紹介寸る（図 17）。 $\mathrm{A} \cdot \mathrm{C}$ 病院の病室において、患者 同士の会話が見られた。また、B病院の 4 床室は、各患者のスペー スが棚で仕切られており、他のベッドサイドや病室外から見えにく い設えとなっている。ベッドサイドで車椅子に座り、テレビを見る 行為が見られた。C 病院では、読書する患者が見られた。

\section{5-2 まとめ: 離床に必要な空間}

表 8 に各病院での離床行為の種類と離床場所をまとめ、離床に必 要な空間について以下に述べる。

（1）自立度の低い患者も、活動性をあげるためにスタッフに見守ら れながら離床する（車椅子やリクライニングチェア等に座りながら 座位を保つ）ことが必要である。これにはスタッフが他のことに関 わりながら見守れる環境が適しており、 $\mathrm{A} \cdot \mathrm{B}$ 病院の食堂や、 $\mathrm{B}$ 病 院においてはスタッフステーション、 $\mathrm{C}$ 病院においては廊下・訓練 スペース（中庭を通して看護の視線が行き届く）がこれにあたる。 （2）自立度が高くなると、患者の離床行為の幅は増えていく。飲食 や趣味・アクティビティなどの行為には、スタッフの視線が行き届 き、また大勢の患者を集めることのできる、まとまった広さの空間 が必要である。 $\mathrm{A} \cdot \mathrm{B}$ 病院の食堂や、 $\mathrm{C}$ 病院の廊下・訓練スペース・ 理学療法室がこれにあたる。また、A 病院のように料理会をアクテ イビティとして取り入れる場合、キッチン等の設備も必要である。 （3）また多くの患者はベッドサイドでも離床して過ごす。ベッドサ イドでは車椅子や椅子に座って滞在するのに十分な広さ、机やテレ ビの設えが必要である（B 病院では TV を枕側の机に置くことで、 離床を促していた)。

（4）自立度の高い患者は、スタッフに用意された行為以外に、様々 な自発的な離床行為が見られた。その中の自主訓練と会話について、 その行為を促す空間について言及する。

・自主訓練が行われる環境

自主訓練は、個別療法で行った訓練内容のうち自分でできるもの を復習として行うことが多いようである（図 16）。C 病院では個別 療法の訓練場所が病棟内という生活の場にあるため、病棟は患者が 生活の中で訓練内容と方法を思い出し反復しや寸い環境であると いえる。また $\mathrm{C}$ 病院の廊下・訓練スペースがスタッフの視線が届き やすい空間で、自主訓練中に事故が起きないよう見守れるというこ

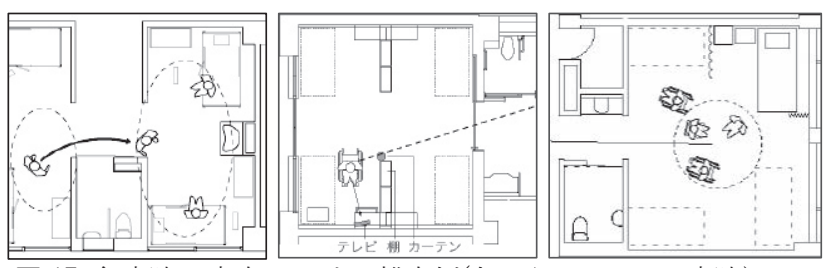

図 17 各病院の病室における離床例(左から $\mathrm{A} 、 \mathrm{~B} 、 \mathrm{C}$ 病院)

表 8 各病院での離床行為の種類と離床場所

\begin{tabular}{|c|c|c|c|c|c|c|c|c|c|}
\hline \multirow[b]{2}{*}{ 離床行為 } & \multicolumn{3}{|c|}{ A病院 } & \multicolumn{3}{|c|}{ B病院 } & \multicolumn{3}{|c|}{ C病院 } \\
\hline & \begin{tabular}{|l} 
食 \\
堂
\end{tabular} & $\begin{array}{l}\text { 病食 } \\
\text { 棟堂 } \\
\text { 共以 } \\
\text { 用外 } \\
\text { 部の }\end{array}$ & $\begin{array}{l}\text { 病 } \\
\text { 室 }\end{array}$ & $\begin{array}{l}\text { 食 } \\
\text { 堂 }\end{array}$ & $\begin{array}{l}\text { 病食 } \\
\text { 棟堂 } \\
\text { 共以 } \\
\text { 用外 } \\
\text { 部の }\end{array}$ & 病 & $\begin{array}{l}\text { 食 } \\
\text { 堂 }\end{array}$ & $\begin{array}{l}\text { 病食 } \\
\text { 棟堂 } \\
\text { 共以 } \\
\text { 用外 } \\
\text { 部の }\end{array}$ & $\begin{array}{l}\text { 病 } \\
\text { 室 }\end{array}$ \\
\hline \begin{tabular}{|l} 
重症患者の \\
離床行為
\end{tabular} & 0 & & & 0 & & & 0 & 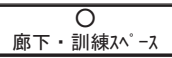 & \\
\hline $\begin{array}{l}\text { 萎・趣味・ } \\
\text { アクティビティ }\end{array}$ & 0 & & & 0 & & & O & $\begin{array}{c}\mathrm{O} \\
\text { 理学療法室 }\end{array}$ & \\
\hline $\begin{array}{l}\text { 歩行訓練 } \\
\text { (個別療法以外) }\end{array}$ & & & & & $\begin{array}{c}\text { 廊下 } \\
\end{array}$ & & & & \\
\hline 自主訓練 & & $\begin{array}{l}\mathrm{O} \\
\text { 廊下 }\end{array}$ & & & & & & $\begin{array}{c}\bigcirc \\
\text { 廊下・訓練スペ-ス }\end{array}$ & \\
\hline 患者同士の会話 & 0 & $\underset{\tilde{T}^{*} \text { 何-t- }}{\mathrm{O}}$ & 0 & & & & & $\begin{array}{c}\mathrm{O} \\
\text { 廊下・訓練スペース } \\
\end{array}$ & 0 \\
\hline その他 & & $\begin{array}{c}0 \\
\tilde{T}^{*} \text { 体t- } \\
\end{array}$ & & & 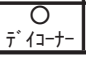 & 0 & 0 & & 0 \\
\hline
\end{tabular}

とが、患者の自由な自主訓練を促しているといえる（中廊下型でス タッフの視線が行き届きにくい $\mathrm{B}$ 病院では、自主訓練は少なく、ス タッフが伴っての歩行訓練（個別療法以外）が行われていた）。

・他患者との会話が行われる環境

$\mathrm{C}$ 病院病室内では中央部で病室の外の訓練の様子等を眺めながら 同室の患者と会話、 $\mathrm{A}$ 病院病室ではトイレ前や 2 ベッド間の洗面所 前で同室の患者と会話する場面が見られ、いずれも個の空間という より、ある程度の広さがあるセミパブリックなスペースで会話が行 われや寸いといえる（個のスペースを重視した設えである B 病院病 室内では会話はほとんど観察されなかった)。また他病院より会話 の多い C 病院病棟共用部では、他患者の個別療法を見ながらの会話 が観察され、訓練空間が生活空間内にあることが患者の会話を促し ているといえる。

\section{6. まとめ}

\section{6-1 3 病院におけるリハ空間}

以上、観察調查から回復期リハのための空間として訓練と離床に 分けて考察した結果として、3 病院における訓練場所と内容、病棟 共用部の性質をまとめる（表 9)。またそれぞれの病院におけるリ八 について以下にまとめる。

1） $\mathrm{A}$ 病院：訓練室やその周辺で ADL 訓練以外のほぼすべての訓練 を行っている。病棟は ADL 訓練以外の訓練をできるだけ持ち込ま ない「生活の場」であり、患者は食堂でのアクティビティなど多様 な生活行為に参加することでリ八効果を得るという、最も生活的な リ八を行っているといえる。

2) B 病院：A病院と同じ<病棟一訓練室分離型>であるが、4 章に 述べたように病棟、訓練室、階段といった病院全体を最大限に利用 して訓練が行われ、また余暇時間にもスタッフによって歩行訓練が 行われるなど、手厚いスタッフ数を利用して「短期間で最大の効果 をあげるためのリ八」を行っているといえる。なお、このスタッフ 数の多さがリ八訓練空間に及ぼす影響についてはさらなる調查が必 
要と考える。

3) $\mathrm{C}$ 病院: 病棟生活に沿った訓練を行うことを目的としたく病棟一 訓練室一体型 $>$ 形態をとっており、ほとんどの訓練を病棟内で行 っている。訓練の場である病棟共用部はどの病室からも近く、また スタッフにとっても看護しや寸い空間であるため、患者の自由な離 床行為が発生している。訓練の場に様々な形での生活が混在し、ま た患者の関わりが活発なリ八の空間となっているといえる。

表 9 各病院における訓練内容と訓練場所

\begin{tabular}{|c|c|c|c|c|}
\hline \multirow{2}{*}{\multicolumn{2}{|c|}{$\begin{array}{c}\text { 訓練に対する } \\
\text { 理念 }\end{array}$}} & A病院 & B病院 & C病院 \\
\hline & & $\begin{array}{c}\text { 「訓練は訓練室で } \\
\text { (病棟は生活の場)」 }\end{array}$ & \multicolumn{2}{|c|}{ 「病棟での生活に沿った訓練を行う」 } \\
\hline \multicolumn{2}{|c|}{$\begin{array}{l}\text { 訓練室の } \\
\text { 設置形態 }\end{array}$} & \multicolumn{2}{|c|}{ <病棟-訓練室分離型＞ } & |<病棟-訓練室－体型＞ \\
\hline \multirow{4}{*}{$\begin{array}{l}\text { 訓 } \\
\text { 練 } \\
\hat{\text { の }} \\
\text { 利 } \\
\text { 用 }\end{array}$} & 病棟 & ほぼADL訓練のみ & $\begin{array}{l}\text { 生活環境において } \\
\text { 可能なあらゆる訓練 }\end{array}$ & ほぼ全ての訓練 \\
\hline & 訓練室 & $\begin{array}{l}\text { ADL訓練以外 } \\
\text { すべての訓練 }\end{array}$ & $\begin{array}{c}\text { 病棟では不可能な } \\
\text { 訓練 }\end{array}$ & - \\
\hline & $\begin{array}{l}\text { 病院内 } \\
\text { その他 }\end{array}$ & $\begin{array}{c}\text { 訓練室周辺の場所 } \\
\text { (ルーフテラー・段) }\end{array}$ & $\begin{array}{c}\text { 病棟と訓練室間の } \\
\text { 階段 }\end{array}$ & $\begin{array}{c}\text { 階段や1 Fの設備 } \\
\text { (和室等) }\end{array}$ \\
\hline & 屋外 & 歩行訓練等に利用 & 歩行訓練等に利用 & 歩行訓練等に利用 \\
\hline \multicolumn{2}{|c|}{$\begin{array}{l}\text { 病棟共用部の } \\
\text { 性質 }\end{array}$} & 主に生活の場 & $\begin{array}{c}\text { 環境は生活環境だが } \\
\text { 訓練の場でももるる }\end{array}$ & $\begin{array}{c}\text { 訓練の場だが } \\
\text { 生活が混在する }\end{array}$ \\
\hline
\end{tabular}

\section{6-2「病棟リハ」のための施設環境}

上記のとおり、一言で「病棟リ八」といっても病院によって異な った性質のリハが行われており、どのようなリ八を行うかによって それにふさわしい施設環境は異なる。訓練の面だけでなく、離床行 為も含めた生活の面からも、リ八空間としての病棟環境・施設環境 を検討することが重要である。

注

注1）ADL（Activities of Daily Living）：日常生活動作。食事・更衣・整 容・排泄・入浴等を指す。

注2）回復期リ八病棟の特徴と施設基準（下記）参照。

\begin{tabular}{|c|c|}
\hline 入院目的 & 2. 寝たきりの防止 \\
\hline 入院適応疾患 & 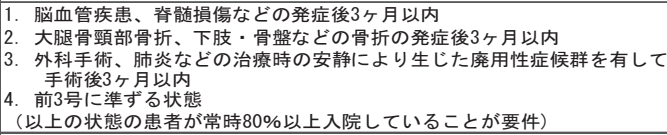 \\
\hline 入院期間 & リハを要する状態ごとに設定されており、60〜180日以内 \\
\hline & 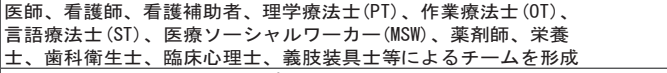 \\
\hline 構造設備基準 & $\begin{array}{l}\mid \text { 病室の床面積が1床あたり } 6.4 \mathrm{~m}^{2} \text { 以上 } \\
\text { 廊下幅が片側居室1.8m以上、両側居室 } 2.7 \mathrm{~m} \text { 以上が望ましい } \\
\text { 障害者に適した浴室とトイレの設置 } \\
\text { 総合リハ施設もしくは理学療法 II ·作業療法 IIの併設※ }\end{array}$ \\
\hline 人員配置基準 & $\begin{array}{l}\text { 病棟専従のリハ科医師 } 1 \text { 名以上 } \\
\text { 看護 } 3: 1 \text { 以上 (40\%以上が看護師) 、看護補助者 } 6: 1 \text { 以上 } \\
\text { 病棟専従のPT2名以上、0T1名以上 }\end{array}$ \\
\hline
\end{tabular}

※総合リ八A 施設はPT (理学療法) に要する専用の施設の面積が $300 \mathrm{~m}^{2}$ 以上、 OT (作業療法) に要する専用の施設の面積が $100 \mathrm{~m}^{2}$ 以上、総合リ八 B 施設 はPT および OT の専用施設の面積が合計 $240 \mathrm{~m}^{2}$ 以上必要とされている。 また理学療法 II +作業療法 II の施設は、PT、OT にそれぞれ $100 \mathrm{~m}^{2}$ 以上が 必要とされている。

注 3) 訓練室 : 回復期リ八病棟取得に必要なリ八施設（注 2 参照）である理 学療法（PT）室・作業療法（OT）室のほか、言語療法（ST）室を含む。

注 4) 患者選定 : 患者の選定については、3 月切たる調查中に回復が見込 まれる患者を、各病院につき脳血管系患者 2 名、整形外科系 2 名の計 4 名 （B 病院についてはほぼ全患者が脳血管系のため、脳血管系患者のみ 2 名）、 という条件で病院に選出いただいた（A 病院患者(1) 3 回目調查日に感染 性疾患に罹っていたため継続観察が不可、A 病院患者(3)・C 病院患者(1)は 途中で退院、 $\mathrm{A}$ 病院患者(4) 3 回目調查を裹権されたため、3 回の調查が 不可能となった）。

注 5）病棟共用部：食堂・デイコーナー・廊下などを示す。

注 6) 日常生活自立度 : 日常生活においてどの程度の自立がなされているかを 示寸指標で、区分は次のとおりである。

\begin{tabular}{|c|c|l|}
\hline 区分 & ランク & \multicolumn{1}{|c|}{ 判定基準 } \\
\hline 生活自立 & $J$ & $\begin{array}{l}\text { 何らかの障害等を有するが、日常生活はほぼ自立しており独力で外 } \\
\text { 出する }\end{array}$ \\
\hline 準寝たきり & A & 屋内での生活は概ね自立しているが、介助なしには外出しない \\
\hline \multirow{2}{*}{ 寝たきり } & B & $\begin{array}{l}\text { 屋内での生活は何らかの介助を要し、日中もべッド上での生活が主 } \\
\text { 体であるが、座位を保つ }\end{array}$ \\
\cline { 2 - 3 } & $\mathrm{C}$ & 1日中ベッド上で過ごし、排泄、食事、着替において介助を要する \\
\hline
\end{tabular}

注 7) 認知症高齢者の日常生活自立度 : 高齢者の認知症の程度を踏まえた日 常生活自立度の程度を表す指標で、区分は次のとおりである。

\begin{tabular}{|c|l|}
\hline ランク & \multicolumn{1}{|c|}{ 判定基準 } \\
\hline I & 何らかの認知症を有するが、日常生活は家庭内及び社会的にほぼ自立している。 \\
\hline II & $\begin{array}{l}\text { 日常生活に支障を来すような症状、行動や意思疎通の困難さが多少見られても、誰 } \\
\text { かが注意していば自立できる。 }\end{array}$ \\
\hline III & ランクI の症状がときどき見られ、介護を必要とする。(徘徊、失禁など) \\
\hline IV & ランクエの症状が頻繁に見られ、常に介護を必要とする。 \\
\hline M & 著しい精神症状や問題行動あるいは、重篤な身体疾患が見られ専門医療を要する。 \\
\hline
\end{tabular}

注 8) 取得日：A・B 病院で幅のある表現になっているのは、病棟によって取 得した時期が違うためである。

注 9）訓練（療法士による単位としての訓練）：回復期リ八病棟では 1 単位 を 20 分とし、患者一人当たり、個別療法で $\mathrm{PT} \cdot \mathrm{OT} \cdot \mathrm{ST}$ 訓練を各 3 単位 日以内、集団療法は 2 単位/日以内、 8 単位/月以内を限度に行う。本論文で は患者の自主訓練は「訓練」には含めず、「離床」に含まれるとする。

注 10）BI（バーセル・インデックス）：生活動作 10 項目（食事・椅子ベッ ド移乗・整容・トイレ動作・入浴・平地歩行・階段・更衣・排泄コントロ ール・排便コントロール）を各 10 点とした 100 点満点で、生活自立度を評 価する指標である。

注 11）ここでは、観察された個別療法（=PT・0T・ST 訓練）のうち、PT・0T 訓練のみに言及する。ST 訓練については、観察調査 1 では ST 訓練が観察 される機会が少なかったこと、また ST 室を利用することが多い訓練である ため観察調査 2 からも十分なデータを得ることはできなかったことから、 ここではST 訓練には言及しないこととした。

注 12) IADL (Instrumental Activities of Daily Living) : 手段的日常生 活動作。料理・洗濯・掃除・布団の上げ下ろしなどの家事、買い物、金銭 管理、趣味活動、公共交通機関の利用、車の運転等、ADL での動作を応用 し、動作の範囲をさらに広げた活動など。

注 13) C 病院病棟には食堂という部屋は設けられていないが、図 13 の分析を 行うにあたり、廊下・訓練スペースの一部（利用者により「食堂」と呼ば れている）の食事テーブルについている状態の患者をカウントした。

注 14）アクティビティ:アクティビティは食堂をはじめ様々な場所で行われ る。A 病院 : 食堂での IADL（料理・手芸等）・体操・カラオケ大会・2 階 サロンでのお茶会。B 病院 : ラウンジでの毎週土曜のコンサート鑑賞・季 節の行事 (祭・餅つき等)。C 病院 : 大勢での共用部・理学療法室での課 題や体力テスト・映画鑑賞・カレンダー作り・中庭を利用した、学生によ る催し物やボランティアによる季節の行事の鑑賞。

\section{参考文献}

1）筧淳夫，井上由起子：回復期リハビリテーション病棟の現状と課題，日本 建築学会大会学術講演梗概集, E-1 分冊, p207, 2002

2）筧淳夫, 井上由起子 : 全国調査からみた回復期リハビリテーション病棟の 実態に関する考察，日本建築学会計画系論文集，No. 571，pp55-61，2003.9

3）筧淳夫，井上由起子：回復期リハビリテーション病棟における患者の ADL 変化について, 日本建築学会大会学術講演梗概集, E-1 分冊, pp75-76, 2006

4）芦沢由紀, 申錦姫，筧淳夫，井上由起子，上野淳 : 回復期リハビリテーシ ヨン病棟の計画要件について, 日本建築学会大会学術講演梗概集, E-1 分 冊, pp209-210, 2005

5）申錦姫，芦沢由紀，筧淳夫，井上由起子，上野淳 : 回復期リハビリテーシ ヨン病棟における患者の生活とその変容について, 日本建築学会大会学術 講演梗概集， E-1 分冊， pp211-212，2005

6）筧淳夫，井上由起子: 治療一療養の場としての回復期リハビリテーション 病棟の建築環境に関する考察, 日本建築学会計画系論文集, No. 613, pp53-58, 2007.3

7）浜村明徳監修，日本リハビリテーション病院・施設協会編集 : これからの 脳卒中リハビリテーション, 青梅社, 2005

8）医療法人社団寿量会熊本機能病院編著: 医療従事者のための回復期リハビ リテーション病棟導入・運営マニュアル 60, 日本医療企画, 2003

9）上田敏, 大川弥生: リハビリテーション医学大事典、医歯薬出版株式会社, 2000 